spreading euonymus (E. Kiautschovica Loes. 'Sieboldiana'. J. Plant Nutr., 1990, 13, 677-699.

11. Spomer, L. A., Cointainer soil-water relations: production, maintenance and transplanting. J. Arboricult., 1980, 6(12), 315-320.

12. Dressboll, D. B., Effect of growing media composition, compaction and periods of anoxia on the quality and keeping quality of potted roses (Rosa sp.). Sci. Hortic., 2010, 126, 56-63.

13. Dubey, R. K., Singh, S., Kukal, S. S. and Kalsi, H. S., Evaluation of different organic growing media for growth and flowering of petunia. Commun. Soil Sci. Plant Anal., 2013, 44, 1777-1785.

14. Awang, Y., Shaharom, S. A., Mohamad, R. B. and Selamat, A., Chemical and physical characteristics of coir-based media mixtures and their effects on the growth and development of Celosia cristata. Am. J. Agric. Biol. Sci., 2009, 4, 63-71.

15. Quinteroa, M. F., González-Murillo, C. A., Florez, V. J. and Guzmánb, J. M., Physical evaluation of four substrates for cut-rose crops. Acta Hortic., 2009, 843, 349-357.

16. Younis, A., Riaz, A., Waseem, M., Khan, A. and Nadeem, M., Production of quality crotons (Codiaeum variegatum) plants using different growing media. Am. Eur. J. Agric. Environ. Sci., 2010, 7, 232-237.

17. Erwan, M. R. I., Saud, H. M., Othman, R., Habib, S., Kausar, H. and Naher, L., Effect of oil plam frond compost amended coconut coir dust soilless growing media on growth and yield of cauliflower. Int. J. Agric. Biol., 2013, 15, 731-736.

18. Rubio, J. S., Pereira, W. E., Garcia-Sanchez, F., Murillo, L., García, A. L. and Martínez, V., Sweet pepper production in substrate in response to salinity, nutrient solution management and training system. Hortc. Bras., 2011, 29(3), 275-281.

19. Ayesha, R., Fatima, N., Ruqayya, M., Qureshi, K. M., Hafiz, I. A., Khan, K. S. and Kamal, A., Influence of different growth media on the fruit quality and reproductive growth parameters of strawberry (Fragaria ananassa). J. Med. Plants Res., 2011, 5(26), 6224-6232.

20. Londra, P., Paraskevopoulou, A. and Psychogiou, M., Hydrological behavior of peat- and coir-based substrates and their effect on begonia growth. Water, 2018, 10(6), 722.

21. Evans, M. R., Konduru, S. and Stamps, R. H., Source variation in physical and chemical properties of coconut coir dust. Hortic. Sci., 1996, 31, 965-967.

22. Blake, G. R. and Hartge, K. H., Bulk density. In Methods of Soil Analysis, Part I (ed. Klute, A.). ASA Monograph No. 9. Madison, WI, USA, 1986, pp. 363-376.

23. Steel, R. G. D. and Torrie, H., Principles and Procedures of Statistics, McGraw-Hill, New York, USA, 1960.

24. Vivek, K., Guerrero, F. M., Tansel, B. and Savabi, M. R., Hydrophysical characteristics of selected media used for containerized agricultural systems. Agric., Water Manage., 2010, 98, 314-320.

25. Starr, Z. W., Boyer, C. R. and Griffin, J. J., Eastern Redcedar (Juniperus virginiana) as a substrate component effects growth of three tree species. J. Environ. Hortic., 2012, 30(4), 189-194.

26. Fornes, F., Belda, R. M., Abad, M., Nougera, P., Puchades, R., Maquieira, A. and Noguera, V., The microstructure of coconut coir dusts for use as alternatives to peat in soilless growing media. Aust. J. Exp. Agric., 2003, 43, 1171-1179.

27. Carlile, W. R., Cattivello, C. and Zaccheo, P., Organic growing media: constituents and properties. Vadose Zone J., 2015, 14(6), $1-13$.

28. Abad, M., Fornes, F., Carrion, C. and Noguera, V., Physical properties of various coconut coir dusts compared to peat. Hortic. Sci., 2005, 40(7), 2138-2144.

29. Munroe, R., McGrath, D. and Henry, J., Increasing amounts of coir dust in substrates do not improve physical properties or growth of tree seedlings in a novel air-pruning propagation tray. J. Environ. Hortic., 2018, 36(3), 92-103.

30. Cresswell, G. C., Coir dust - a viable alternative to peat? In Proceedings of the Australian Potting Mix Manufacturers Conference, Sydney, 1992, pp. 1-5.
31. Beven, K. and Germann, P., Macropores and water flow in soils Water Resour. Res., 1982, 18(5), 1311-1325.

32. Hillel, D., L'eau et Ie sol, principes et processus physiques. Ed. Academia, Louvain-la-Neuve, Belgium, 1988, p. 288.

ACKNOWLEDGEMENTS. We thank the Head, Department of Soil Science and Estate Officer, Punjab Agricultural University (PAU), Ludhiana for providing the necessary facilities to carry out research at the PAU Landscape Nursery.

Received 29 December 2018; revised accepted 22 February 2019

\section{Avian mortalities from two wind farms at Kutch, Gujarat and Davangere, Karnataka, India}

\author{
Selvaraj Ramesh Kumar ${ }^{1, *}$, V. Anoop ${ }^{2}$, \\ P. R. Arun ${ }^{2}$, Rajah Jayapal ${ }^{2}$ and \\ A. Mohamed Samsoor Ali $^{2}$ \\ ${ }^{1}$ Bombay Natural History Society, Mumbai 400 001, India \\ ${ }^{2}$ Sálim Ali Centre for Ornithology and Natural History, \\ Coimbatore 641 108, India
}

Wind power is renewable and helps reduce greenhouse gas emission from the energy sector; however, it also has undesirable impacts on the environment. Studies from Europe and the USA report negative impact of wind farms on wildlife, especially on birds. India, the fourth largest producer of wind energy and also a mega biodiverse country has little information on this issue. Here, we report bird collisions from two wind farms: one at Kutch, Gujarat in western India and another from Davangere, Karnataka in southern India. A total of 47 bird carcasses belonging to at least 11 species in a period of three years were reported from Kutch and seven carcasses of at least three species in a period of one year were recorded at Davengere wind farm. The estimated annual bird mortality rate for Kutch was 0.478 birds/turbine and for Davengere it was 0.466 birds/turbine.

Keywords: Avian mortality, bird collisions, carcasses, wind turbines.

WIND power is one of the fastest growing renewable energy sectors in the world ${ }^{1}$. India is the fourth largest producer of wind energy with an installed capacity of

*For correspondence. (e-mail: ramesh.wild@gmail.com) 
32,280 MW as of March 2017, with a target of $60 \mathrm{GW}$ by 2022 (ref. 2). Tamil Nadu, Maharashtra, Gujarat, Rajasthan and Karnataka are the leading states where most wind turbines are installed ${ }^{2}$. Although wind power is considered as a green energy source, there are negative impacts of wind farms on wildlife ${ }^{3}$. Wind farms affect terrestrial mammals ${ }^{4}$ and reptiles ${ }^{5}$, but the most affected groups are birds and bats ${ }^{6,7}$. The rotating blades of the wind turbine cause bird collisions ${ }^{8}$. Apart from bird collision which is considered as the major impact of wind turbines, other noted negative impacts include displacement of birds from the turbine area ${ }^{9}$, changes in territorial behaviour of birds due to turbine noise ${ }^{10}$ and habitat alteration $^{6}$.

This issue came to light after large-scale raptor mortality was documented at the Attamount Pass, USA in 1990 (ref. 11). Since then, bird mortality at wind farms has been extensively studied in Europe and North America $^{8,12,13}$ but remains poorly studied in Asia ${ }^{14,15}$. In India, there have been few studies on the effect of wind farms on bats and birds. The existing two studies are from Maharashtra and Gujarat ${ }^{16,17}$. Considering the rich diversity of avifauna with 554 important bird areas (IBA) spread all across the country ${ }^{18}$, the rapid increase of wind turbines ${ }^{1}$ needs to be examined for their possible impacts on native avifauna.

The present study explored bird collisions with wind turbines at two wind farms; one located in the Samakhiali region, Kutch district, Gujarat and the other in the Harapanahalli region, Davangere district, Karnataka. Both wind farms are located in entirely different habitats; Samakhiali is a coastal area located close to the Little Rann of Kutch and Harapanahalli is a hilly area in central Karnataka. The specific aim of this study was to document avian collisions and provide an estimate of the annual mortality rate for these two wind farms.

Samakhiali wind farm is located in the Samakhiali region of Kutch district $\left(23^{\circ} 15^{\prime} 5.1^{\prime \prime}-23^{\circ} 11^{\prime} 21.72^{\prime \prime} \mathrm{N}\right.$ and $\left.70^{\circ} 30^{\prime} 8.68^{\prime \prime}-70^{\circ} 38^{\prime} 24.68^{\prime \prime} \mathrm{E}\right)$. The high winds and flat terrain close to the Arabian Sea make it a suitable location for wind-power generation, and has resulted in a large number of wind turbines being set-up in the area since 2003. This wind farm comprises about 200 turbines and covers $\sim 120$ sq. km area, and majority of the turbines are of $1.8 \mathrm{MW}$ capacity with $95 \mathrm{~m}$ hub height and rotor diameter of $100 \mathrm{~m}$.

The area is generally dry and arid, dotted with many seasonal wetlands. Barren lands with the invasive tree Prosopis juliflora predominate the landscape, with a small number of rainfed agricultural fields. Most of the rainfall is received during July to September. Kutch district has four important bird and biodiversity areas ${ }^{18}$, among which the Wild Ass Wildlife Sanctuary (Little Rann of Kutch) is close to the study area and few turbines are located $\sim 200 \mathrm{~m}$ from the sanctuary boundary. The region is also a stopover site for birds migrating through
Central Asian Flyway (CAF), that makes it a bird-rich area with 174 species of birds (observations by S.R.K. and A.M.S.A.). We selected 59 turbines for the carcass search, of which 51 turbines belong to a private wind farm company which requested this study. The remaining eight turbines were selected on the basis of easy access from the road. However, the selected turbines were scattered across the wind farm in different habitats like agricultural fields, barren land and close to saltpans.

Harapanahalli wind farm is located in the Harapanahalli region of Davangere district $\left(14^{\circ} 45^{\prime} 11.57^{\prime \prime}-14^{\circ} 53^{\prime} 3.78^{\prime \prime} \mathrm{N}\right.$ and $\left.75^{\circ} 47^{\prime} 36.75^{\prime \prime}-75^{\circ} 50^{\prime} 54.47^{\prime \prime} \mathrm{E}\right)$. The selected wind farm has 24 wind turbines located in 56 sq. km area. All the turbines are of $1.5 \mathrm{MW}$ capacity, with $78 \mathrm{~m} \mathrm{hub}$ height and rotor diameter of $82 \mathrm{~m}$. This study was conducted on the request of a private wind farm company; hence all the turbines (24) belonging to that company were selected for the study. There are about 75 wind turbines located $10 \mathrm{~km}$ from the present location, which is not covered in the study. The wind farm is a part of 'Hyarada Block-C Reserved Forests', a dry deciduous forest surrounded by human settlements. The elevation ranges from 500 to $800 \mathrm{~m}$. This area is dominated by Ziziphus mauritiana and Terminalia crenulata. It also has many small wetlands within $5 \mathrm{~km}$ radius of the wind farm and River Tungabhadra flows about $12 \mathrm{~km}$ west of the study area. The study area has a rich avifaunal diversity with about 115 species of birds (pers. obs. by V.A., P.R.A. and R.J.).

Carcass surveys were conducted at the selected 59 turbines from October 2011 to July 2014 in Samakhiali. Totally, 23 cycles of search were conducted at each turbine. The average gap between two consequent searches was 40.5 days. In Harapanahalli wind farm, nine cycles of search were conducted in 24 wind turbines from January 2014 to February 2015, with an average gap of 40 days.

At both wind farms, $130 \mathrm{~m}$ radial area around each selected turbine was searched by slowly walking along a spiral path outwards from the centre ${ }^{12}$. On most occasions, two persons surveyed Samakhiali wind farm, whereas one person searched for carcass at Harapanahalli. The time spent on searching a turbine site was approximately 30-40 $\mathrm{min}$. When a carcass or feather-spot (feather and bone remaining) ${ }^{19}$ was found, data on species, condition of carcass and distance from the turbine base were recorded. Bird nomenclature as provided by Praveen et $a l .{ }^{20}$ was followed. The study covered both migratory (October-March) and non-migratory (AprilSeptember) periods of the birds. There was not much difficulty in locating the carcasses at both wind farms; hence the detection probabilities for both wind farms were assumed as 1 , i.e. the observer could detect all the carcasses which were available below the turbine during a search. The injuries observed in some carcasses (like broken leg, injuries on the head, broken wing) revealed that death was caused by collision of birds with the wind 


\section{RESEARCH COMMUNICATIONS}

Table 1. List of bird collisions at Samakhiali wind farm, Kutch, Gujarat (between October 2011 and July 2014 from 59 turbines locations and 23 rounds of search) and Harapanahalli wind farm, Davanagere, Karnataka (between January 2014 and February 2015 from 24 turbines)

\begin{tabular}{|c|c|c|c|c|c|c|}
\hline \multirow[b]{2}{*}{ Family } & \multirow[b]{2}{*}{ Common name } & \multirow[b]{2}{*}{ Scientific name } & \multirow{2}{*}{$\begin{array}{c}\text { Resident } \\
\text { status }\end{array}$} & \multirow{2}{*}{$\begin{array}{l}\text { IUCN } \\
\text { status }\end{array}$} & \multicolumn{2}{|c|}{ No. of bird mortalities } \\
\hline & & & & & Samakhiali & Harapanahalli \\
\hline Ardeidae & Black-crowned night heron & Nycticorax nycticorax & $\mathrm{R}$ & $\mathrm{LC}$ & 1 & - \\
\hline Ardeidae & Cattle egret & Bubulcus ibis & $\mathrm{R}$ & $\mathrm{LC}$ & $4(1)$ & - \\
\hline Dicruridae & Black drongo & Dicrurus macrocercus & $\mathrm{R}$ & $\mathrm{LC}$ & $1(1)$ & - \\
\hline Charadriidae & Red-wattled lapwing & Vanellus indicus & $\mathrm{R}$ & $\mathrm{LC}$ & 1 & - \\
\hline Columbidae & Rock pigeon & Columba livia & $\mathrm{R}$ & $\mathrm{LC}$ & $6(1)$ & - \\
\hline Columbidae & Eurasian collared dove & Streptopelia decaocto & $\mathrm{R}$ & $\mathrm{LC}$ & $10(1)$ & - \\
\hline Corvidae & House crow & Corvussplendens & $\mathrm{R}$ & $\mathrm{LC}$ & 4 & - \\
\hline Falconidae & Common kestrel & Falco tinnunculus & WV & $\mathrm{LC}$ & $4(1)$ & - \\
\hline Pelecanidae & Dalmatian pelican & Pelecanus crispus & WV & VU & $1(1)$ & - \\
\hline Strigidae & Pallid Scops owl & Otus brucei & WV & $\mathrm{LC}$ & $1(1)$ & - \\
\hline Alcidinidae & White-throated kingfisher & Halcyon smyrnensis & $\mathrm{R}$ & $\mathrm{LC}$ & - & 1 \\
\hline \multicolumn{3}{|c|}{ Unidentified raptors of family Accipitridae } & & & $5(2)$ & 1 \\
\hline \multicolumn{3}{|c|}{ Other unidentified taxa } & & & 8 & 2 \\
\hline \multicolumn{3}{|l|}{ Total } & & & 47 & 7 \\
\hline
\end{tabular}

The number of carcasses used for scavenger removal test is given in parenthesis. R, Resident; WV, Winter visitor; LC, Least concern; NT, Near threatened and VU, Vulnerable.

turbine. Most of the existing studies have failed to determine the cause of death of the birds recorded below wind turbines, as the probability of natural deaths within the search area was not significant ${ }^{19,21}$.

Bird carcasses following collisions may be scavenged by dogs, jackals and other scavenger species between two consequent searches. The major scavengers seen in the study area during our surveys included Bengal monitor (Varanus bengalensis), Golden jackal (Canis aureus) and domesticated dog (Canis familiaris). This bias can be corrected using scavenger removal tests, which determine the average number of days that a bird carcass remains in the search area below the turbine before being removed by scavengers ${ }^{22}$. We used ten bird carcasses belonging to ten different species (three fresh; seven old/scavenged carcasses with only feathers and bones) for this test from Samakhiali wind farm. The smallest species used was black drongo, Dicrurus macrocercus and the largest was Dalmatian pelican Pelecanus crispus (see Table 1 for species used for carcass test). No statistical test was performed to assess the role of body size in scavenger removal due to low sample size. Only two carcasses were used from Harapanahalli wind farm (Table 1). The mean length of time a carcass remained on a plot $(T)$ was calculated based on the following equa$\operatorname{tion}^{12,22}$

$$
T=\sum t_{i} / S
$$

where $t_{i}$ is the total length of time a carcass remained on the site and $S$ is the total number of carcasses planted for the study.
The estimated number of annual fatalities $(M)$ was calculated for the Samakhiali and Harapanahalli wind farms separately using the following formula ${ }^{23}$

$$
M=\frac{N \times I \times C}{k \times T}
$$

where $N$ is the total number of turbines, $I$ the interval between searches (days), $C$ the total number of carcasses found, $k$ the number of turbines sampled and $T$ is the mean length of time the carcasses remained on the site before being scavenged. The mortality rate per turbine was estimated by dividing $M$ (estimated number of annual fatalities of the wind farms) by the number of turbines present.

In Samakhiali wind farm, 47 bird mortalities belonging to 11 species (eight resident and three winter visitors), including globally threatened Dalmatian pelican (vulnerable) and near-threatened painted stork were recorded (Table 1). Eurasian collared dove had maximum number of collisions (ten individuals), followed by rock pigeon (six individuals), common kestrel, cattle egret and house crow, each with four mortalities. In all, five carcasses were identified to family level (Accipitridae) and eight could not be identified to family level as they were scavenged beyond recognition. Among the 47 mortalities, 43 were recorded in the migratory season (October to March) and four during non-migratory season (April to September). Among the 59 turbines searched, 37 turbine locations had bird carcasses recorded. All the carcasses were recorded within $80 \mathrm{~m}$ from the base of the turbine and maximum number of carcasses (21) was recorded within $20 \mathrm{~m}$ from turbine base (Figure 1). 
The simple average of bird collision for 59 turbines was 0.27 birds/turbine/year. The estimated annual mortality rate using the scavenger removal formula was 0.47 birds/turbine/year (over two years and ten months). Three fresh carcasses (pallid scops owl; rock pigeon and cattle egret) and seven scavenged carcasses (only feathers were remaining) found during the search were left as such for the scavenger removal test. On an average the fresh carcasses remained intact in the field for $1.3 \pm 0.57$ (SD) days. However, the feathers of carcasses lasted for $23.7 \pm 13$ SD days. Since most of our records of carcasses were from feather remains, we used 23.7 days as the residence time for estimation of annual mortality rate. However, there are chances that fresh carcasses might have been carried away entirely by scavengers without trace, and it is likely that smaller birds may disappear entirely in a short period of time.

In Harapanahlli, seven bird mortalities belonging to at least three species were recorded (average 0.29 birds/ year/turbine). The bird carcasses observed included Indian pitta, white-throated kingfisher, little swift, one unidentified raptor (family accipitridae) and two other unidentified taxa (Table 1). In all, four carcasses were recorded in the migratory season and three during the nonmigratory season. None of the species recorded was listed as threatened by IUCN. Among the three species, one (Indian pitta) is a winter visitor and other two are residents of the study area. All bird carcases were recorded within $60 \mathrm{~m}$ from the turbine base (average: $21.5 \mathrm{~m}$ ) (Figure 2). Two fresh carcasses (Indian pitta and little swift) were left in the field and monitored daily for the scavenger removal rate estimation. The mean length of time a carcass remained on a plot $(T)$ was 2.5 days. The estimated annual bird mortality rate for the Harapanahalli wind farm was 0.466 birds/turbine (1.5 MW capacity).

Our study documented mortality of birds owing to collision with wind turbines from two wind farms. The number and species of birds involved in collisions were

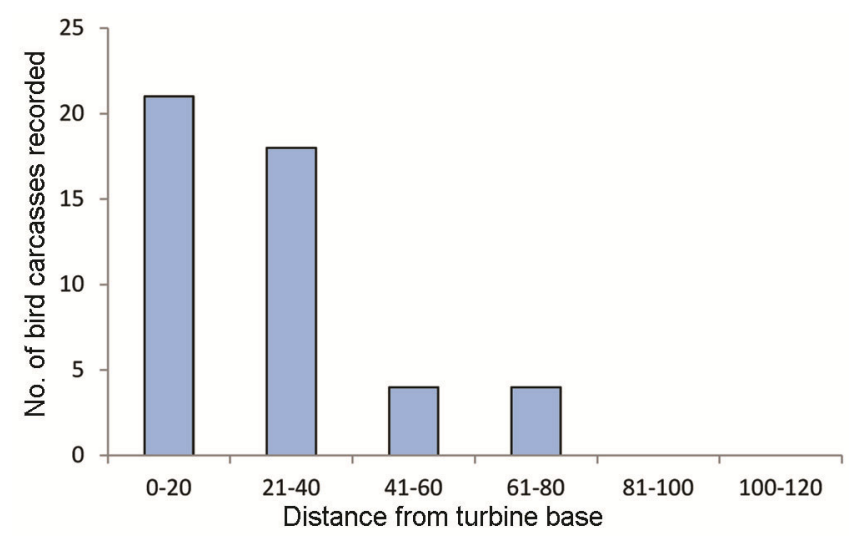

Figure 1. Distance from the turbine base at which carcasses were recorded in Samakhiali wind farm, Kutch, Gujarat (surveyed between October 2011 and July 2014 from 59 turbines locations). different. No common species were observed in Samakhiali and Harapanahalli wind farm mortalities. However, the family Accipitridae was found to be affected in both the wind farms and also from another study in India ${ }^{16}$. Raptor mortalities were reported from bird collision studies in USA, UK and Europe ${ }^{8,13}$. Apart from raptors, Eurasian collared dove and rock pigeon were killed in more numbers at Samakhiali wind farm. Similar to this observation, high number of rock pigeon mortalities was reported from many wind farms in $\mathrm{USA}^{8}$. The water bird mortalities at Samakhiali could be due the presence of numerous wetlands within the wind farm. Similarly, for Indian pitta in the forested area of Harapanahalli, the collisions mainly depend on the bird composition present at the wind farm.

At Samakhiali, most of the carcasses were recorded during the migratory season when the area is extensively used by migratory birds. The resident birds also faced mortality during winter; this suggests the role of other parameters such as climatic conditions in determining bird mortalities. For instance, it is reported that bad weather conditions can cause high bird mortalities ${ }^{12}$. Although the estimated annual mortality rate for Samakhiali was 0.47 birds/turbine/year (over two years and ten months), this estimation could be lower as smaller carcasses could have been removed by scavengers and such bias of carcass size is not accounted in our estimation. The fresh carcasses we planted for bias correction test were removed in about two days. Hence, in future studies more frequent searches (minimum weekly twice) will give a better understanding of the mortality patterns. There is further chance that the estimated mortality rate in this study may be on the lower side because we assumed searcher efficiency as $1(100 \%)$. The mortality rates reported in studies from other countries showed large variation; for example, from 0 to $64 \mathrm{birds} /$ turbine annually among wind farms ${ }^{13}$. Studies that show high mortality rates include a report of 64.26 birds/turbine/

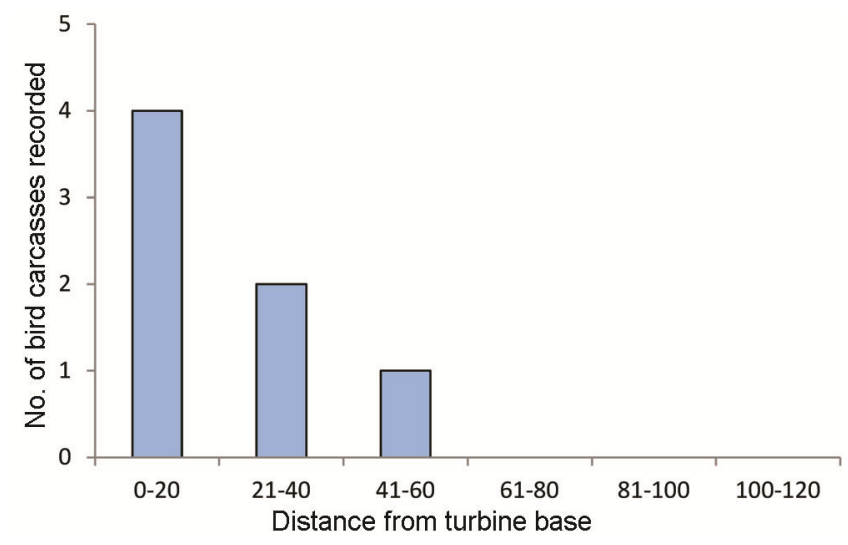

Figure 2. Distance from the turbine base at which carcasses were recorded in Harapanahalli wind farm, Davanagere, Karnataka (surveyed between January 2014 and February 2015 from 24 turbines). 


\section{RESEARCH COMMUNICATIONS}

year at El Perdón, Spain ${ }^{13,24}, 54$ birds/turbine/year in Solano County, USA ${ }^{8}$, and 35 birds/turbine/year in Boudewijnkanaalte Brugge, Belgium ${ }^{25}$. In contrast to such high records of bird mortalities, studies conducted at Green Mt, Searsburg and Algona, USA reported zero bird mortality ${ }^{8}$.

Species affected also vary based on the geographical and climatic features. More than the number of birds killed, the type of species getting killed is of concern. Raptors are the most affected group of birds worldwide by wind turbines and the present study is yet another proof of this. The long-term impacts of wind farms on raptors are of greater concern, because they produce few offspring and have a long life expectancy and occupy the top of the food chain $^{26}$. A study conducted in Spain showed that wind farms are a serious threat to the longliving raptors, as they decrease the survival rates of this species and increase the chance of extinction ${ }^{27}$.

Apart from direct collisions, the displacement of bird species from wind turbines should also be taken into consideration $^{9}$. For instance, wind turbines installed in the habitat of critically endangered species such as the Great Indian bustard Ardeotis nigriceps may seriously affect the very survival of these birds through habitat alteration. In Harapanahalli, we found, that roads were constructed on many small hillocks and these hilltops were flattened for turbine installation. This led to extensive destruction of vegetation cover in the area, otherwise a dry deciduous forest habitat for many bird species.

Considering the increased power consumption in India, the renewable sources of power production have to be tapped but the impacts on avifauna should also be borne in mind. The present study indicates the potential impacts of wind turbines on birds. Various mitigation measurements are being followed in some places, including automatic shutdown of turbines whenever a high-risk situation occurs (e.g. bird flocks approaching the high collision risk zone), or restriction of operation during certain times of the day or seasons when bird activity is high in the area. Increasing wind turbine visibility for the birds using appropriate methods, placing bird deterrents and habitat management, including creation of alternative feeding areas ${ }^{28}$, can also help in the mitigation of impacts by wind farms. Further large-scale experimental data are needed to confirm the effectiveness of these practices in mitigating wind-farm bird collisions. We strongly recommend detailed bird monitoring studies before installation of wind turbines. Careful selection of windfarm sites based on avifaunal importance of these sites, and implementation of appropriate management and mitigation options can definitely help reduce the impacts of wind farms on birds to a large extent.

1. GWEC, Global Wind Report, Annual Market Update, 2016, p. 73.

2. Indian Wind Turbine Manufacturers Association, Status update. Indian Wind Power, 2017, 3, 40.

3. Subramanian, M., An ill wind. Nature, 2012, 486, 310-311.
4. Helldin, J. A. et al., The impacts of wind power on terrestrial mammals, Swedish Environmental Protection Agency, Stockholm, Sweden, 2012, p. 51.

5. Lovich, J., Assessing the Long-Term Survival and Reproductive Output of Desert Tortoises at a Wind Energy Facility near Palm Springs, California, USGS, Flagstaff, AZ, 2015, p. 51.

6. Drewitt, A. L. and Langston, R. H. W., Assessing the impacts of wind farms on birds. Ibis, 2006, 148, 29-42.

7. Jain, A. A., Koford, R. R., Hancock, A. W. and Zenner, G. G., Bat mortality and activity at a Northern Iowa wind resource area. Am. Midl. Nat., 2011, 165, 185-200.

8. Erickson, W. P. et al., Avian Collisions with Wind Turbines : A Summary of Existing Studies and Comparisons to Other Sources of Avian Collision Mortality in the United States, Western Ecosystems Technology, WEST Inc., Cheyenne, 2001, p. 62 .

9. Shaffer, J. A. and Buhl, D. A., Effects of wind-energy facilities on breeding grassland bird distributions. Conserv. Biol., 2016, 30, 59-71.

10. Zwart, M. C., Dunn, J. C., Mcgowan, P. J. K. and Whittingham, M. J., Wind farm noise suppresses territorial defense behavior in a songbird. Behav. Ecol., 2016, 27, 101-108.

11. Orloff, S. and Flannery, A., Wind turbine effects on avian activity, habitat use, and mortality in Altamont Pass and Solano Count wind resource areas: 1989-1991. A report prepared for California Energy Commission, California, 1992, p. 199.

12. Kerns, J. and Kerlinger, P., A study of bird and bat collision fatalities at the Mountaineer Wind Energy Center, Tucker County, West Virginia: Annual Report for 2003. A Report prepared for FPL Energy and Mountaineer Wind Energy Center, West Virginia, 2004, p. 39.

13. Hötker, H., The Impact of Repowering of Wind Farms on Birds and Bats, Michael Otto Institute NABU, Bergenhusen, Germany, 2006, p. 37.

14. Sugimoto, H. and Matsuda, H., Collision risk of white-fronted geese with wind turbines. Ornithol. Sci., 2011, 10, 61-71.

15. Tajiri, H. et al., Relationship between flight route selection of wintering white-fronted geese and weather conditions, and foraging sites in the vicinity of Awara Wind Farm, Fukui Prefecture, central Japan. J. Field Ornithol., 2013, 29, 1-16.

16. Pande, S. et al., Avian collision threat assessment at 'Bhambarwadi Wind Farm Plateau' in northern Western Ghats, India. J. Threat. Taxa, 2013, 5, 3504-3515.

17. Kumar, S. R., Ali, A. M. S. and Arun, P. R., Bat mortality due to collision with wind turbines in Kutch District, Gujarat, India. J. Threat. Taxa, 2013, 5, 4822-4824.

18. Rahmani, A. R., Islam, M. Z. and Kasambe, R. M., Important Bird and Biodiversity Areas in India: Priority Sites for Conservation (Revised and updated). Bombay Natural History Society, Indian Bird Conservation Network, Royal Society for the Protection of Birds and BirdLife International (UK), 2016, p. 1992.

19. Hull, C. L., Stark, E. M., Peruzzo, S. and Sims, C. C., Avian collisions at two wind farms in Tasmania, Australia: taxonomic and ecological characteristics of colliders versus non-colliders. NZ J. Zool., 2013, 40, 47-62.

20. Praveen, J., Jayapal, R. and Pittie, A., A checklist of the birds of India. Indian Birds, 2016, 11, 113-170.

21. Smallwood, K. S. and Karas, B., Avian and bat fatality rates at old-generation and repowered wind turbines in California. J. Wildl. Manage., 2009, 73, 1062-1071.

22. Erickson, W. P., Jeffrey, J., Kronner, K. and Bay, K., Stateline Wind Project Wildlife Monitoring Final Report, July 2001December 2003, WEST Inc., Cheyenne and Northwest Wildlife Consultants, Inc., Pendelton, 2004.

23. Strickland, M. D., Johnson, G. D., Erickson, W. P., Sarappo, S. A. and Halet, R. M., Avian use, flight behavior, and mortality on the Buffalo Ridge, Minnesota, wind resource area. In Proceedings of 
the National Avian-Wind Power Planning Meeting III (eds Erickson et al.), San Diego, California, USA, 1998, pp. 70-79.

24. Lekuona, J. M., Uso del espacio por la avifauna y control de la mortalidad de aves y murciélagos en los parques eólicos de Navarra durante un ciclo annual, Pamplona, 2001.

25. Everaert, J., Collision victims on 3 wind farms in Flanders (Belgium) in 2002, Instituut voor Naturbeheer, Brussels, Belgium, 2003.

26. Bellebaum, J., Korner-Nievergelt, F., Dürr, T. and Mammen, U., Wind turbine fatalities approach a level of concern in a raptor population. J. Nat. Conserv., 2013, 21, 394-400.

27. de Lucas, M., Ferrer, M., Bechard, M. J. and Muñoz, A. R., Griffon vulture mortality at wind farms in southern Spain: distribution of fatalities and active mitigation measures. Biol. Conserv., 2012, 147, 184-189.
28. Teresa, A. et al., Understanding bird collisions at wind farms : an updated review on the causes and possible mitigation strategies. Biol. Conserv., 2014, 179, 40-52.

ACKNOWLEDGEMENTS. We thank M/s Genting Energy Pvt Ltd, Hyderabad, CLP Wind Farms (India) Ltd and Vestas Pvt Ltd., Harapanahalli for financial and logistical support for this study. We also thank the Director; Salim Ali Centre for Ornithology Natural History Society, Coimbatore for encouragement and support. S.R.K. thanks the Director, Bombay Natural History Society (BNHS), Mumbai for his support. We thank Neha Sinha (BNHS) for editing an earlier version of this manuscript.

Received 1 March 2018; revised accepted 20 February 2019

doi: $10.18520 / \mathrm{cs} / \mathrm{v} 116 / \mathrm{i} 9 / 1587-1592$

\section{GURRENT SGIENGE \\ Display Advertisement Rates}

\begin{tabular}{|c|c|c|c|c|c|c|c|}
\hline India & \multicolumn{7}{|c|}{ Tariff (Rupees)* } \\
\hline \multirow[b]{2}{*}{ Size } & \multirow{2}{*}{$\begin{array}{c}\text { No. of } \\
\text { insertions }\end{array}$} & \multicolumn{2}{|c|}{ Inside pages } & \multicolumn{2}{|c|}{ Inside cover pages } & \multicolumn{2}{|c|}{ Back cover pages } \\
\hline & & B\&W & Colour & B\&W & Colour & B\&W & Colour \\
\hline \multirow{7}{*}{$\begin{array}{l}\text { Full page } \\
\left(\begin{array}{l}(H=23 \mathrm{~cm} \\
W=17.5 \mathrm{~cm})\end{array}\right.\end{array}$} & 1 & 18,000 & 30,000 & 25,000 & 40,000 & 35,000 & 45,000 \\
\hline & 2 & 33,000 & 55,000 & 47,000 & 76,000 & 65,000 & 86,000 \\
\hline & 4 & 62,000 & $1,05,000$ & 92,000 & $1,46,000$ & $1,25,000$ & $1,65,000$ \\
\hline & 6 & 90,000 & $1,50,000$ & $1,25,000$ & $2,00,000$ & $1,75,000$ & $2,25,000$ \\
\hline & 8 & $1,10,000$ & $1,87,000$ & $1,68,000$ & $2,65,000$ & $2,30,000$ & $3,00,000$ \\
\hline & 10 & $1,35,000$ & $2,25,000$ & $1,98,000$ & $3,15,000$ & $2,70,000$ & $3,60,000$ \\
\hline & 12 & $1,80,000$ & $3,00,000$ & $2,50,000$ & $4,00,000$ & $3,50,000$ & $4,50,000$ \\
\hline \multirow{7}{*}{$\begin{array}{l}\text { Half page } \\
\left(\begin{array}{l}(H=11 \mathrm{~cm} ; \\
W=17.5 \mathrm{~cm})\end{array}\right.\end{array}$} & 1 & 10,000 & 18,000 & \multirow{7}{*}{$\begin{array}{l}\text { Quarter page } \\
\begin{array}{l}(\mathrm{H}=11 \mathrm{~cm} ; \\
\mathrm{W}=8 \mathrm{~cm})\end{array}\end{array}$} & \multirow{2}{*}{$\begin{array}{c}\text { No. of } \\
\text { insertions }\end{array}$} & \multicolumn{2}{|c|}{ Inside pages } \\
\hline & 2 & 19,000 & 33,000 & & & B\&W & Colour \\
\hline & 4 & 35,000 & 62,000 & & 1 & 6,000 & 12,000 \\
\hline & 6 & 50,000 & 90,000 & & 6 & 30,000 & 60,000 \\
\hline & 8 & 60,000 & $1,10,000$ & & 12 & 60,000 & $1,20,000$ \\
\hline & 10 & 72,000 & $1,35,000$ & & & & \\
\hline & 12 & $1,00,000$ & $1,80,000$ & & & & \\
\hline $\begin{array}{c}\text { Other } \\
\text { Countries }\end{array}$ & \multicolumn{7}{|c|}{ Tariff (US \$) ${ }^{*}$} \\
\hline \multirow[b]{2}{*}{ Size } & \multirow{2}{*}{$\begin{array}{c}\text { No. of } \\
\text { insertions }\end{array}$} & \multicolumn{2}{|c|}{ Inside pages } & \multicolumn{2}{|c|}{ Inside cover pages } & \multicolumn{2}{|c|}{ Back cover pages } \\
\hline & & B\&W & Colour & B\&W & Colour & B\&W & Colour \\
\hline \multirow{2}{*}{$\begin{array}{l}\text { Full page } \\
(\mathrm{H}=23 \mathrm{~cm} ; \\
\mathrm{W}=17.5 \mathrm{~cm})\end{array}$} & 1 & 300 & 650 & 450 & 750 & 600 & 1000 \\
\hline & 6 & 1500 & 3000 & 2250 & 3500 & 3000 & 5000 \\
\hline \multirow{2}{*}{$\begin{array}{l}\text { Half page } \\
(H=11 \mathrm{~cm} ; \\
W=17.5 \mathrm{~cm})\end{array}$} & 1 & 200 & 325 & & & & \\
\hline & 6 & 1000 & 2000 & & & & \\
\hline
\end{tabular}

* $25 \%$ rebate for Institutional members

Note: For payments towards the advertisement charges, Cheque (at par/multicity) or Demand Drafts may be drawn in favour of 'Current Science Association, Bengaluru'.

Contact us: Current Science Association, C.V. Raman Avenue, P.B. No. 8001, Bengaluru 560080 or e-mail: csc@ias.ac.in

Last date for receiving advertising material: Ten days before the scheduled date of publication.

[The jurisdiction for all disputes concerning submitted articles, published material, advertisement, subscription and sale will be at courts/tribunals situated in Bengaluru city only.] 